\title{
KAMULAH SAHABAT-SAHABATKU (Yoh. 15:14-15)
}

\author{
Siprianus S. Senda \\ Program Studi Ilmu Filsafat, Fakultas Filsafat Universitas Katolik Widya Mandira \\ Jl. Prof. Dr. Herman Yohanes - Penfui - Kupang - NTT \\ Email: sipri_senda@yahoo.co.id
}

\begin{abstract}
The text of Jn 15:14-15 speaks of the friendship between Jesus and His disciples, between God and man. Jesus, The Logos became flesh (Jn 1:14), reveals in Himself a God who befriends man and gives His own life because of the love of friends (Jn 15:13). The initiative in this relationship is God, and therefore being His friends is a gift, a condition of 'grace'. For Jesus, the disciples are friends and not servants. The reason for this fact is given both by the commandment of love and the knowledge of the revelation of Jesus. Thetext of John15:14-15is part of thechapter, showsthatthe secondfarewell discourseat the Last Supper, and is divided into2 parts: the metaphorof the vine (15:1-17) andthe hatred of theworld (15:1827). Many scholarsdivided thefirst partinto two sections; the metaphor of thevine and the branches (15:1-11) andthe commandment of love (5:12-17). Therearemany differences betweenservantand friend, butinthis verse of (15:15), Jesus clearlyshows only onethat is knowledge. Aservant does not knowwhathis master is doing, so he does nothave the knowledgeof the secretsof the master. Instead, Jesus gaveto His discipleswhat he hadheard from His Father. They, then, have the knowledge. Jesushasrevealed to themHisdivine mysteries, its secrets, andwhenthe disciplesse, know andaccept them, andstillbelievein Him, they become friends (cf. Jn1:35-51; 2:11; 6:68-69; 14:1-31a). The knowledgeof His secrets, then, is the central pointthat distinguishesthem as friends.
\end{abstract}

Kata kunci: sahabat, hamba, kasih, mengetahui, iman

\section{Pendahuluan}

Hukum Gereja menegaskan bahwa Katekese adalah model pelayanan Sabda ilahi yang diarahkan kepada orang-orang yang telah menerima pesan Injil dan menanggapinya dalam iman. Nampaknya Katekese membuat iman hidup, ekspplisit dan operatif dalam hidup dan karya semua umat beriman kristiani.

Tulisan ini menyajikan tanggung jawab kaum beriman kristiani baik yang terbaptis maupun yang tertahbis atas penyampaian ajaran Kristen menurut perspektif Hukum Kanonik. Hukum Gereja menegaskan bahwa para pastor adalah penanggungjawab utama pengajaran Katekese disusul tanggungjawab semua umat beriman kristiani. Ada delapan kanon ${ }^{1}$ dalam Kitab Hukum Kanonik 1983 yang menjadi payung hukum bagi umat beriman kristiani dalam memainkan peran dan tanggungjawabnya sebagai pengajar Katekese kepada sesamannya dalam kehidupan Gereja di tengah dunia masa kini.

Secara sistematis, tulisan ini terdiri dari lima bagian. Kelima bagian tersebut adalah: pertama, pengantar, kedua, pengajaran kateketik,ketiga, para imam adalah penanggungjawab utama pengajaran katekese, keempat, tujuan katekese dan kelima,

${ }^{1}$ KHK.1983 Kan.773-780 
penutup. Teks Yoh 15:14-15 berbicara tentang persahabatan antara Yesus dan para muridNya, antara Allah dan manusia. Yesus, Sang Logos berinkarnasi (Yoh 1:14), mewahyukan dalam diriNya Allah yang bersahabat dengan manusia dan memberikan hidupNya karena cinta kepada sahabat-sahabatNya (Yoh 15:13). Inisiatif dari relasi istimewa ini adalah Allah sendiri, karena itu keberadaan sebagai sahabatNya merupakan sebuah anugerah. Bagi Yesus, para muridNya bukanlah hamba, melainkan sahabat. Alasannya termaktub dalam perintah cinta kasih maupun dalam tanggapan manusia terhadap pewahyuan diri Yesus. Ada dua kelompok ekseget yang menelaah hal ini dengan perbedaan pandangan. Yang pertama menempatkan kasih sebagai alasan keberadaan sebagai sahabat, sedangkan yang kedua melihat dimensi pengetahuan terhadap pewahyuan diri Yesus sebagai alasan keberadaan tersebut.Tulisan ini membahas pernyataan Yesus kepada para murid sebagai sahabat dengan memperbandingkan pandangan kedua kelompok ekseget ini, seraya menelaah teks tersebut dan menggali kekayaan teologinya.

\section{Pembahasan}

\subsection{Perbandingan Pandangan Ekseget}

R.E. Brown menggarisbawahi istilah filos atau sahabat, bahwa istilah ini merupakan istilah khas Yohanes yang muncul sangat sering dalam injilnya. Kata kerja fileoo atau mengasihi sangat sering muncul dan hal itu menunjukkan bahwa kata sahabat atau filos sebenarnya berakar pada kata kerja mengasihi. Maka pengertian sahabat di sini adalah "yang dikasihi". Ini berarti keberadaan sebagai sahabat Yesus memiliki makna mendasar yaitu dikasihi oleh Yesus. ${ }^{2}$

Menurut R. Schnakenburg, tema sahabat sangat penting dan umum dalam dunia Yunani-romawi, khususnya dalam kaitan dengan keberanian untuk mati demi sahabat. Dalam teks ini, keberadaan sebagai murid Yesusmenggarisbawahi kebenaran bahwa status itu merupakan sebuah anugerah yang mengangkat para murid dari keadaan sebagai hamba menjadi sahabat. Anugerah ini merupakan motivasi bagi para murid untuk memenuhi perintah cinta kasih dari Yesus karena Dia telah mempercayakan kepada mereka semua yang telah didengarNya dari BapaNya. ${ }^{3}$

R. Fabris menekankan pemberian anugerah sebagai sahabat kepada para murid sebagai ungkapan kasih Yesus. Konsekuensinya kemuridan sejati semestinya terungkap dalam penghayatan kasih seperti Yesus.Anugerah tersebut mengangkat para murid pada status sahabat, maka mereka dipanggil untuk menghayati status sahabat itu dalam praksis cintakasih timbal balik sebagaimana diperintahkanNya (Yoh 15:14.17). ${ }^{4}$ Dalam nada yang sama, S. Grasso menyatakan bahwa para murid menjadi sahabat Yesus mereka mengalami kasih Yesus yang menggerakkan mereka untuk mengasihi

\footnotetext{
${ }^{2}$ R. E. BROWN, Giovanni, (Assisi: Cittadella, 2005), hlm. 801.

${ }^{3}$ R. SCHNACKENBURG, II Vangelo di Giovanni, vol. 3, (Brescia:Paideia,1981), 179-181. Cfr. R. SCHNACKENBURG, Le parole di commiato di Gesù (Gv. 13-17), (Brescia: Paideia, 1994), hlm. 49.

${ }^{4}$ R. FABRIS, Giovanni, (Roma: Borla, 1992), hlm. 819.
} 
yang lain dalam kasih timbal balik. Hanya dengan anugerah kasih yang mengangkat status para murid ke tingkat sahabat, mereka dipanggil untuk membagi hidup mereka kepada yang lain dengan melaksanakan perintah cintakasih yang diberikan Yesus. ${ }^{5}$

Bagi F.J. Maloney, persahabatan antara Yesus dan para murid adalah suatu hubungan baru yang didasarkan pada kasihNya yang murah hati, tanpa usaha dan perjuangan dari para murid untk mendapatkannya sebagaimana yang terjadi pada para hamba. Sebaliknya mereka disebut sahabat karena mereka dikasihi Yesus tanpa batas. ${ }^{6}$ Selanjutnya J. Mateos dan J. Baretto membahas tema persahabatan antara Yesus dan para muridNya berdasarkan penghayatan cintakasih yang membawa keserupaan mereka dengan Yesus.Maka keberadaan sebagai murid dibasiskan pada relasi personal dengan Yesus yang memerintahkan mereka untuk melaksanakan hukum kasih sesuai Roh cintakasih Yesus.Keduanya menekankan peranan Roh Kudus, Roh cintakasih yang menggerakkan para murid untuk mengasihi sebagai saudara. ${ }^{7}$

U. Wilckens sebaliknya menggarisbawahi pengetahuan para murid mengenai pewahyuan diri Yesus sebagai Putra Allah oleh karena kasih. Baginya, mengetahui dan mengenal Yesus itulah yang menjadi alasan mereka dipanggil sebagai sahabat, dan bukannya hamba, karena hamba dalam posisinya tidak mengetahui dan mengenal apa yang dikerjakan tuannya. ${ }^{8}$ Demikian pula bagi $\mathrm{H}$. Strathmann, teks ini berbicara tentang para murid yang mengenal pewahyuan diri Yesus, dan karena itu mereka mesti melaksanakan perintahNya, yaitu perintah cintakasih. Yesus menyebut mereka sahabat karena Dia telah memberikan mereka kepercayaan penuh, bahwa mereka mengetahui segala rahasia yang diterima dari BapaNya.Hal ini tentu saja tidak pernah dilakukan terhadap hamba. ${ }^{9}$

$\mathrm{X}$. Léon-Dufourmelihat bahwa percaya dan mengasihi yang dihayati para murid di hadapan pewahyuan tentang rahasia keintiman sang Putra sebagai alasan Yesus memanggil mereka sahabat. Istilah "hamba" dalam kitab suci, memiliki makna percaya tanpa syarat kepada Allah, sekaligus mengekspresikan suatu kondisi kemuridan di hadapan Putra Allah yang datang dari atas. ${ }^{10}$ Sementara R. Cecolin menggambarkan peralihan dari hamba menuju sahabat dalam bentuk pola relasi yang terjadi dalam rumah tangga. Pelayan atau hamba dalam rumah tangga tentu saja tidak ikut ambil bagian dalam hal-hal rahasia keluarga. Hamba tidak tahu apa yang diperbuat tuannya, sebaliknya seorang sahabat mengetahui apa yang diperbuat tuan dari hamba tersebut. Hal inipun berlaku pada relasi antara para murid dengan Yesus yang menjadi sahabatNya karena mereka mengetahui rahasia misteri Bapa yang diwahyukan melalui Yesus.Maka Yesus menjadi perantara dalam hubungan antara manusia dengan Allah, yang menutup status hamba, seraya membuka ruang bagi stastus manusia bebas, yang

${ }^{5}$ S. GRASSO, Il Vangelo di Giovanni. Commento esegetico e teologico, (Roma: Città Nuova, 2008), hlm. 621.

${ }^{6}$ F. J. MOLONEY, II Vangelo di Giovanni, (Torino: Elledici, 2007), hlm. 371.

7 J. MATEOS - J. BARRETTO, II Vangelo di Giovanni. Analisi linguistica e commento esegetico, (Assisi: Cittadella, 1982), hlm. 623.

${ }^{8}$ U. WILCKENS, II Vangelo secondo Giovanni,(Brescia: Paideia, 2002), hlm. 305.

${ }^{9}$ H. STRATHMANN, II Vangelo Secondo Giovanni, (Brescia: Paideia, 1973), hlm. 363-364.

${ }^{10}$ X. LÉON-DUFOUR, Lettura dell'evangelo secondo Giovanni, (Milano: San Paolo, 2007), hlm. 892. 
bersahabat dan familiar dengan Allah, terbuka kepada Allah, sebagaimana Dia terbuka dan mewahyukan diriNya melalui Putra. ${ }^{11}$

Dari semua pandangan di atas, terlihat perbedaan argumentasi dari para ekseget mengenai tema ini. Di satu sisi ada kelompok ekseget yang membasiskan argumentasi mereka pada perintah kasih sebagai alasan penyebutan para murid sebagai sahabat: R.E. Brown, R. Schnackenburg, R. Fabris, F.J. Moloney, J. Mateos - J. Barretto, S. Grasso. Menurut mereka, pelaksanaan hukum baru, hukum cintakasih, merupakan kunci prerogatif keberadaan sebagai sahabat Yesus (ay 14). Sedangkan kelompok kedua yang meliputi U. Wilckens, H. Strathmann, X. Léon-Dufour, R. Cecolin menekankan pewahyuan rahasia Yesus kepada para murid, yakni penekanan pada pengetahuan akan pewahyuan tersebut sebagai alasan penyebutan mereka sebagai sahabat (ay 15).

\subsection{Teks dan Konteks}

Teks Yoh 15: 14-15 merupakan bagian dari bab tentang diskursus Yesus dalam perjamuan malam terakhir. Diskursus kedua ini dibagi atas dua bagian, yaitu metafora tentang pokok anggur (15:1-17) dan kebencian dunia (15:18-27). ${ }^{12}$ Mayoritas ekseget membagi lagi bagian pertama di atas menjadi dua subbagian yaitu metafora pokok anggur dan carang-carangnya (15:1-11) dan perintah cintakasih (15,12-17). ${ }^{13}$ Teks ini akan dilihat dalam konteks jauh dan konteks dekat.

\section{a. Kontek Jauh}

Diskursus tentang pokok anggur dan ranting-rantingnya (Yoh 15:1-27) merupakan salah satu dari tiga diskursus Yesus pada perjamuan malam terakhir, sebelum Ia meninggalkan dunia ini dan kembali kepada Bapa (Yoh 13:1). Kedua diskursus lainnya ditemukan pada bab 14:1-31 dan bab 16:4b-33, yang berkaitan dengan tema yang mirip, yaitu kembalinya Yesus kepada Bapa dengan semua motivasi dan konsekuensinya, serta kedatangan Roh Kudus. ${ }^{14}$

Yoh 15 merupakan salah satu tipe diskursus yang disebut mashal, ${ }^{15}$ yakni suatu gaya literer ibrani yang merujuk baik pada tindakan simbolik yang diungkapkan melalui bahasa figuratif, maupun kalimat pepatah atau peribahasa yang berbasis parenetis atau nasihat hidup. ${ }^{16}$ Teks ini bukanlah teks narasi melainkan diskursus atau wejangan.Melalui bentuk sastra diskursus

\footnotetext{
${ }^{11}$ R. CECOLIN, Gesù è la vera vigna: possibilità e condizioni di fecondità (Gv 15,1-16,3), dalamParole di Vita 4 (2004), hlm. 38.

${ }^{12}$ Cfr. R. SCHNACKENBURG, I/ Vangelo di Giovanni, vol. 3, hlm. 151.

${ }^{13} \mathrm{lbid}$., hlm. 155. Cfr. R. SCHNACKENBURG, Le parole di commiato di Gesù (Gv. 13-17), hlm. 49; R. FABRIS, Giovanni, hlm. 806; M. ORSATTI, Giovanni il Vangelo "Ad Alta Definizione", (Milano: Ancora, 1999), hlm. 171; Y. SIMOENS, Secondo Giovanni. Una traduzione e un'interpretazione, (Bologna: EDB, 2002), hlm. 611-612. S. A. PANIMOLLE, Lettura pastorale del vangelo di Giovanni,vol. 3, (Bologna: EDB, 2002), 256; R. CECOLIN, Gesù è la vera vigna, hlm. 34 dan 36; F. J. MOLONEY, II Vangelo di Giovanni, hlm. 365; S. GRASSO, Il vangelo di Giovanni, hlm. 610.

${ }^{14}$ Cfr. R.E. BROWN, Giovanni, hlm. 648-649.

${ }^{15} / \mathrm{lbid}$., hlm. 806.

${ }^{16}$ M. MAZZEO, Vangelo e lettere di Giovanni, hlm. 161. Cfr. A. POPPI, I quattro vangeli, hlm. 645.
} 
pengarangnya hendak memperkenalkan ajaran fundamental tentang persatuan antara Yesus dengan Bapa dan para murid, tentang cintakasih dan konsekuensi dari kebersatuan dengan diriNya. Teks Yoh 15:14-15 berada dalam konteks diskursus kedua yang berbicara tentang metafora pokok anggur dan rantingrantingnya serta nilai dari tinggal bersatu dengan Dia (Yoh 15,1-11), tentang memelihara perintah kasihNya (Yoh 15,12-17), dan juga tentang perkataanNya mengenai kebencian dan kekerasan dunia terhadap diriNya maupun para muridNya (Yoh 15,18-27). ${ }^{17}$

Bagian pertama dari diskursus ini adalah sebuah ekspresi simbolik yang digambarkan melalui metafora tentang pokok anggur dan ranting-rantingnya (ay1-11), kemudian dilanjutkan dengan sebuah ajakan yang diperkenalkan melalui bentuk parenesi atau nasihat tentang cintakasih (ay 12-17). Sesudahnya digambarkan dengan bahasa profetik mengenai konsekuensi dari kebersatuan dengan Yesus (ay 18-27). Dengan kata lain, melalui gambaran pokok anggur dan ranting-ranting, Yesus menghadiahkan tiga warisan: persatuan dengan Yesus dan Bapa, cintakasih satu sama lain, dan anugerah Roh Kudus dalam menghadapi kebencian dunia. Ketiga hal ini merupakan anugerah perjanjian, dengannya para murid dapat menghasilkan buah dalam hidup internal (kasih persaudaraan), dan hidup eksternal (berkanjang dalam menghadapi kebencian dunia). Gambaran tentang pokok anggur dalam dunia yahudi telah sering dihubungkan dengan bangsa Israel. ${ }^{18}$ Namun di sini dengan benderang diaplikasikan pada diri Yesus dengan pernyataan penuh kuasa "Aku adalah". Horison yang ditunjukkan di sini adalah tentang keharusan berada dalam persatuan secara mendalam dan vital dengan Dia. ${ }^{19}$

\section{b. Kontek Dekat}

Konteks dekat teks Yoh 15:114-15 adalah perikop yang berbicara tentang cintakasih resiprokal yang diwariskan Yesus kepada para muridNya (Yoh 15:1217). Ayat 12 dan 17 mengapiti perikop ini dengan ekspresi yang sama: perintah untuk saling mengasihi satu sama lain. pada ayat 13 ditampilkan contoh atau teladan dari Yesus dalam hal mengasihi yakni menyerahkan nyawa bagi sahabatsahabatNya. Dari titik ini, berkembanglah tema keberadaan sebagai sahabat sebagai sebuah berkat istimewa, sebuah pewarisan yang mengangkat mereka pada status baru (ay 14-15). Warisan ini adalah sebuah anugerah terterima, serentak pula sebuah tugas yang wajib dilaksanakan: Gabe (anugerah/hadiah) dan serentak pula Aufgabe (tanggung jawab).

Dengan demikian, terwujudlah otoritas Dia yang akan segera pergi, seraya menganugerahkan warisan berharga bagi para muridNya. Dia pun memberi tugas missioner kepada mereka yang menerima warisan cintakasih itu (ay 16a). Hadiah atau anugerah ini diberikan pada momen yang persis tepat waktu, yang membuka ruang bagi masa depan mereka yang ditinggalkan. Mereka yang ditinggalkan diberikan garansi berupa kemungkinan untuk meminta dengan penuh imanapa

\footnotetext{
${ }^{17}$ Ibid..

${ }^{18}$ Cfr. Yes 5:1-7; Hos 10:1; Mzr 79:9-10; Yer 2:21-22; Yeh 19:10-14.

${ }^{19}$ Cfr. S.A. PANIMOLLE, L'evangelista Giovanni, (Roma: Borla, 1985), 568.
} 
saja kepada Bapa yang murah hati, yang akan memberikannya (ay 16b). Perkembangan tema persahabatan (ay 14-15) diungkapkan dalam sebuah hubungan mendalam yakni keberadaan sebagai murid Yesus sejajar dengan keberadaan yang menyatu dengan Dia.

\subsection{Menjadi Sahabat Yesus}

Ide tentang sahabat yang menyerahkan nyawa bagi sahabatnya telah dikenal umum dalam dunia yunani pada masa itu. R. Schnackenburg mengutip Aristoteles mengatakan bahwa tentang seorang lelaki bangsawan berlaku perkataan bahwa ia melakukan segalanya bagi sahabatnya, dan bila perlu, ia menyerahkan nyawanya bagi mereka. ${ }^{20}$ Gambaran ini biasa dan lumrah dalam relasi sosial pada waktu itu, karena dilakukan oleh orang-orang dalam status sosial yang sama. Namun hal ini akan berbeda manakala diterapkan pada Yesus. Ada satu sudut pandang yang berbeda. Di sini Yesus bertindak sebagai seorang Guru dan Tuhan bagi para muridNya (bdk. Yoh 13:13). Dengan demikian, kedua pihak tidak berada dalam status yang sama. Dalam dunia yahudi seorang guru memiliki status di atas para murid. ${ }^{21}$ Posisi Yesus lebih tinggi di atas para murid karena Dia adalah Tuhan, Guru, Putra Allah (bdk. Yoh 3,18; 5,17-23; 10,36). Meski demikian, Yesus sebagai seorang sahabat, mengangkat status dari para murid ke tingkat menjadi sahabat-sahabatNya. Serentak pula dalam waktu yang sama, Dia merendahkan diriNya sebagai seorang sahabat sejati, yang menyerahkan nyawaNya bagi para sahabat, sampai sampai mati, bahkan sampai mati di salib (bdk. Flp 2:8). Oleh karena itu, Yesus tidak dapat diperbandingkan dengan siapapun di seluruh dunia (Yoh 15:13).

Yesus menggarisbawahi tema persahabatan ini dengan ungkapan: Kamulah sahabat-sahabatKu. Ungkapan ini dapat dipadankan dengan ungkapan lain pada bagian sebelumnya dalam bab 15 yaitu ayat 1 dan ayat 5. Pada kedua ayat ini, terdapat ungkapan otoritas yang lazim dipakai Yesus dalam banyak kesempatan yaitu Aku adalah. Ayat 1 berbunyi: Aku adalah pokok anggur yang benar, dan BapaKulah pengusahanya. Ayat 5 berbunyi: Akulah pokok anggur yang benar, dan kamulah ranting-rantingnya. Pada ayat 13 Yesus menggambarkan diri secara implisit bahwa Dia adalah seorang sahabat yang sejati. Selanjutnya pada ayat 14a Yesus menyebut para murid sebagai sahabat-sahabatNya. Jika kedua ayat ini digabungkan, maka akan terlihat pola yang sama pada ayat 1 dan terutama ayat 5: Akulah Sahabat yang sejati, dan kamulah sahabat-sahabatKu. ${ }^{22}$ Ungkapan "Kamulah sahabat-sahabatKu" menyatakan sebuah kepastian keberadaan spesifik dari para murid sebagai sahabatsahabat Yesus. Eksistensi baru ini merupakan sebuah hadiah gratis yang berasal dari otoritas kreatif Yesus sebagai Tuhan, Guru dan juga Sahabat Sejati. Maka para murid

\footnotetext{
${ }^{20} \mathrm{R}$. SCHNACKENBURG, Le parole di commiato di Gesù (Gv. 13-17), hlm. 49.

${ }^{21}$ Cfr. K. H. RENGSTORF, "dida, skaloj", dalamGrande Lessico del Nuovo Testamento, vol. 2, hlm. 1142.

${ }^{22}$ Kelihatan bahwa R. Schnackenburg memandang Yesus Kristus sebagai Sang Hidup yang terus hidup dalam orang beriman, dan menganggap Yesus sebagai Sahabatku, Sahabat semua manusia: cfr. R. SCHNACKENBURG, Amicizia con Gesù, (Brescia: Morcelliana, 2007), hlm. 7 dan 55.
} 
sungguh merupakan sahabat-sahabat Yesus, kepada siapa Dia mempercayakan seluruh rahasia dari Bapa, dan untuk siapa Dia menyerahkan hidupnya sampai mati oleh karena kasih. Dengan demikian, jelas bahwa menjadi sahabat berarti menyatu dengan Yesus; itulah sebuah eksistensi baru.

Yesus dalam tindakannya mengangkat para murid ke eksistensi baru sebagai sahabat-sahabatNya, tidak sekedar bertindak tanpa alasan. Dalam bagian selanjutnya Dia menjelaskan kondisi esensial yang menyebabkan terjadinya perubahan status itu. Yesus yang akan segera meninggalkan dunia ini, tentu mempunyai harapan bahwa para muridNya, seraya menyatu dan tinggal dalam Dia, menjadi sahabat yang menghayati perintahNya saat kini dan nanti. Harapan itu dibasiskan pada kebebasan para murid untuk melaksanakan semua yang telah diperintahkanNya.Para murid, selain memiliki kebebasan tersebut, juga memiliki pengetahuan tentang rahasia yang diwahyukan karena mereka telah melihat, mendengarkan, mengenal dan percaya (bdk. Yoh 1:39; $2: 11.23 ; 6: 68 ; 8: 30 ; 12: 44-50$ ) bahwa inilah jalan sejati menuju kepenuhan keselamatan atau kehidupan kekal, yang diwahyukan sendiri oleh Putra Allah. ${ }^{23}$

Kamulah sahabatKu jika kamu melakukan apa yang Kuperintahkan kepadamu. Ekspresi kondisional di sini memperlihatkan bahwa afirmasi mengenai keberadaan sebagai sahabat-sahabat Yesus bukanlah dibangun di atas penalaran eksistensi-kausal tetapi penalaran moral-ekshortatif. Dengan kata lain bukan tentang hal yang menyebabkan eksistensi, melainkan hal yang harus dilakukan atau dihayati. Dalam teologi moral ada sebuah adagium: agere sequitur esse. ${ }^{24}$ Maka melakukan apa yang diperintahkan Yesus sesungguhnya tidak terlepas dari keberadaan sebagai muridmuridNya. Para murid mentaati perintah kasih sebagaimana Yesus mengasihi mereka. Pada titik ini dapat disimpulkan bahwa pernyataan tersebut berkaitan dengan sebuah bentuk parenetis-ekshortatif kepada para murid sebagai sahabat-sahabat Yesus. Mereka diminta untuk melakukan apa yang harus dilakukan untuk mengungkapkan keberadaan mereka sebagai sahabat. Saling mengasihi satu sama lain adalah tindakan prinsipil dari keberadaan sebagai sahabat. ${ }^{25}$

Selanjutnya Yesus menjelaskan dan menggarisbawahi keberadaan sebagai sahabat dengan perbandingan antara sahabat dan hamba. Kamu bukanlah hamba, karena seorang hamba tidak tahu apa yang diperbuat tuannya. Yesus sebagai Tuhan dan Guru tidak memposisikan para muridNya sebagai hamba. Pernyataan Yesus bahwa para murid bukanlah hamba menunjukkan bahwa Yesus tidak memiliki kebiasaan menyebut para muridNya hamba. Mereka telah dipilihNya untuk berada menyatu dengan Dia dalam komunitas persahabatan dan kasih, yang dibentuk dari persatuan dengan Allah Bapa, Putra Allah dan Roh Penghibur.Dalam komunitas kasih ini tidak ada perhambaan apapun. Penyebutan seseorang sebagai hamba menunjukkan adanya hubungan perhambaan, yang menegasi kebebasan dan solidaritas. Jika Yesus menyebut

${ }^{23}$ C.K. BARRETT, The Gospel according to St. John.An Introduction with Commentary and Notes on the Greek Text, (London: S.P.C.K., 1965), hlm.398.

${ }^{24}$ Cfr. R.M. PIZZORNI, II diritto naturale dalle origini a S. Tommaso d'Aquino, (Bologna: Edizioni Studio Domenicano, 2000), hlm. 557.

25 Cfr. F.F. SEGOVIA, "The Theology and Provenance of John 15:1-17", dalamJournal of Biblical Literature 101, 1 (1982), hlm. 125. 
para muridnya sebagai hamba, maka mereka berada dalam perhambaan, dan itu berarti misiNya sungguh bertentangan total dengan keberadaanNya.

Seorang hamba tidak tahu apa yang diperbuat tuannya. Jelas bahwa aktivitas sang tuan bukanlah objek pengetahuan dari hamba. Pengetahuan si hamba terpusat melulu pada apa yang harus dilakukan seturut perintah dari tuannya. Keberadaan sebagai hamba merupakan status yang sangat rendah dalam status sosial waktu itu, dan dia dianggap selevel dengan binatang atau harta benda. Karena itu dia tidak punya kemampuan maupun hak untuk mengetahui apa yang diperbuat tuannya. Dia tidak diperkenankan mengetahui rahasia tuannya. Hamba tidak selevel dengan tuannya dan para sahabatnya. Dengan penjelasan itu, Yesus menggarisbawahi bahwa status hamba tidak cocok bagi para muridNya. Menurut F. Manns, persahabatan Yesus dengan para muridNya telah terbentuk sejak pemilihan para murid. ${ }^{26} \mathrm{Hal}$ ini berarti baik waktu lampau, masa sekarang maupun yang akan datang, keberadaan sebagai sahabat tak kan tergantikan oleh keberadaan sebagai hamba. Bahkan tidak bisa dipahami bahwa sebelumnya mereka adalah hamba tetapi sekarang menjadi sahabat. Komunitas yang dibangun Yesus bersama para murid sejak dari awal mula, sekarang dan sepanjang masa, selalu merupakan komunitas persahabatan, yang di dalamnya keberadaan sebagai sahabat telah ditetapkan oleh Yesus sebagai anugerah.

Di hadapan Yesus yang mewahyukan diriNya, para murid menerima pewahyuan itu dalam arti melihat-mengetahui-percaya-tinggal di dalam Dia. Ada kesejajaran makna antara tindakan membuat mereka mengetahui dan tindakan menerima pewahyuan. Pengetahuan akan pewahyuan diri Yesus menjelaskan alasan utama keberadaan sebagai sahabat. Sahabat berarti mereka yang melihat, mengetahui, percaya dan tinggal di dalam Dia. Sahabat berarti mereka memiliki keberadaan sebagai sahabat dan mengasihi seturut cara mengasihiNya. Jadi ada hubungan antara pengetahuan dan iman. Dari segi semantik, kata kerja melihat-mengetahui-percaya-berdiammemiliki makna pengetahuan dan iman. (bdk. Yoh 6:40.69; 15:4; 17:8). Hasil dari melihat adalah mengetahui atau memahami; objek dari pengetahuan ini adalah Yesus, sang Sabda yang menjadi daging, yang mewahyukan Allah. Jadi pengetahuan itu melahirkan iman akan Dia dalam hubungan istimewa, tempat berdiam selamanya untuk memperoleh hidup kekal. Siapa yang mengetahui kebenaran berada dalam iman. ${ }^{27}$

Yesus dengan jelas menunjukkan bahwa pengetahuan adalah unsur yang membedakan antara hamba dan sahabat. Kata melihat dan mengetahui tentu saja berisi konsep tentang pengetahuan. Seorang hamba tidak mengetahui apa yang dilakukan tuannya, maka ia tidak memiliki pengetahuan tentang rahasia tuannya. Sebaliknya Yesus telah memberitahukan semua yang didengarNya dari BapaNya.Maka mereka memiliki pengetahuan. Inilah unsur pembedanya, bahwa mereka bukan hamba melainkan sahabat Yesus telah mewahyukan kepada mereka misteri ilahinya, dan saat itu para murid melihatnya, mengetahuinya, menerimanya dan percaya kepadaNya, serta tinggal di dalam Dia. Mereka saat itupun menjadi sahabat-sahabatNya (bdk. Yoh.

\footnotetext{
${ }^{26}$ F. MANNS, "Je vous appelle mes àmis", dalamBibbia e Oriente38, 190 (1996), hlm. 234.

${ }^{27}$ Cfr. O. MICHAEL, "pi, stij", dalamDizionario dei concetti biblici del Nuovo Testamento, hlm. 624; R. BULTMANN - A. WEISER, Fede nel Nuovo Testamento, (Brescia: Paideia, 1995), hlm. 124; D.M. SMITH, La teologia del vangelo di Giovanni, (Brescia: Paideia, 1998), hlm. 123.
} 
$1: 35-51 ; 2: 11 ; 6: 68-69 ; 14: 1-31 a)$. Pengetahuan tentang rahasiaNya merupakan titik sentral yang membedakan antara hamba dan sahabat. ${ }^{28}$

Dengan kata lain, pengetahuan tentang pewahyuan diri Yesus adalah motif keberadaan sebagai sahabat. Itulah titik eksistensi baru bahwa mereka menjadi sahabatsahabat Yesus.Status baru ini memiliki konsekuensi esensial untuk menghayati hidup sekian sehingga menampakkan eksistensi baru tersebut. Dalam aktus mengasihi (Yoh $13: 34 ; 14: 15 ; 15: 10.12 .17)$ sebagai aktus utama dari keberadaan sebagai sahabat, terwujudkanlah identitas sejati dari sahabat. ${ }^{29}$ Maka perlu digarisbawahi bahwa alasan utama dari keberadaan sebagai sahabat Yesus dalam diskursus ini, bukanlah karena kasih, melainkan karena pengetahuan akan pewahyuan. Pengetahuan itu adalah iman. Dengan iman para murid melihat, mengetahui, percaya dan tinggal dalam Yesus Kristus, Putra Allah, Sabda yang menjadi daging, yang datang dari Bapa.Dengan iman, mereka menjadi sahabat-sahabat Yesus.Konsekuensi dari beriman adalah mengasihi sebagai aktus utama dari keberadaan sebagai sahabat.

\subsection{Menggagas Pesan Teologis}

\section{Kristologi}

Yesus Kristus adalah Sahabat Sejati yang mewahyukan Bapa kepada para murid. Berkat pewahyuan itu, para murid mengetahui segala yang didengar Yesus dari Bapa.Pengetahuan itu mendatangkan status baru sebagai sahabat. Gambaran pokok anggur dan ranting-ranting mengekspresikan secara simbolik peranan Yesus sebagai Pewahyu hidup, iman, keberadaan sebagai sahabat dan kasih.

Pewahyuan Yesus membuka ruang misteri ilahi bagi manusia, dan serentak menegaskan kapasitas manusia untuk mengetahuinya. Melaluinya diwujudkan pula sebuah dunia baru yakni hubungan istimewa antara Allah yang mewahyukan diri dan manusia yang mengenalNya.Itulah dunia relasi baru yakni persahabatan. Allah hadir dan menjadi sahabat bagi manusia. Pengetahuan dan pengenalan manusia akan Allah yang mewahyukan diri terwujud dalam iman yang bertumbuh dari kedalaman diri manusia. Iman itu mempersatukan manusia dengan Yesus Pewahyu.Persatuan itu menampak sebagai ikatan persahabatan timbal balik. ${ }^{30}$ Dalam Yesus Pewahyu, para murid mengenal pribadi, kehendak dan karya Bapa. ${ }^{31}$

Kehidupan kekal telah dimulai sejak momen pewahyuan Yesus dikenal melalui iman atau aktus percaya yang terus bergerak dinamis menuju kedalaman dengan pelaksanaan perintah cintakasih. Maka keberadaan sebagai sahabat

${ }^{28}$ Cfr. C.K. BARRETT, The Gospel according to St. John, hlm.396.

${ }^{29}$ Cfr. F.F. SEGOVIA, "The Theology and Provenance of John 15:1-17", hlm.125; A. CASALEGNO, "Fede ed esperienza nella teologia di San Giovanni", hlm. 310; J.C. DILLOW, "Abiding Is Remaining in Fellowship: Another Look at John 15:1-6", hlm. 50; G. SEGALLA, Teologia biblica del Nuovo Testamento, (Torino: Elledici, 2006), hlm. 502.

${ }^{30} \mathrm{Cfr}$. A. CASALEGNO, "Fede ed esperienza nella teologia di San Giovanni", hlm. 309.

${ }^{31}$ Cfr. E. BOVONE, "La fede nel Vangelo di Giovanni", dalamParole di Vita 3 (1971), hlm. 226. 
Yesus menjadi sebuah bentuk hidup kekal yang direalisasikan dari kekuatan kreatif sang Pewahyu yang diutus Bapa. Hidup kekal adalah sebuah hadiah, namun serentak di dalamnya ada tanggung jawab untuk tinggal di dalam Dia dan menghasilkan buah melalui pelaksanaan perintah cintakasih.

Peranan Yesus sebagai Pewahyu yang ditanggapi manusia dengan iman menghasilkan sebuah status baru bagi para murid yakni menjadi sahabat. Pada titik ini dapat dipahami bahwa Yesus sendiri adalah Sang Sahabat Sejati. Dialah model bagaimana menjadi sahabat sejati karena Dia sendiri telah memberi contoh yakni memberikan nyawa kepada para sahabatNya atas dasar kasih, karena Dia sungguh mengasihi mereka sampai sehabis-habisnya (Yoh 13,1). Dengan memanggil para murid ke dalam persahabatan dengan diriNya, Yesus memperkenalkan diriNya sebagai model dari persahabatan otentik. Para murid di lain pihak mendedikasikan diri bersamaNya dalam misi yang diproyekkan oleh Bapa. Mereka bukanlah hamba, melainkan sahabat yang mengetahui segala rahasia dan bersama Yesus bekerja dalam tugas perutusan yang sama. ${ }^{32}$

\section{Eklesiologi}

Dari segi eklesiologis, istilah tinggal bersama Yesus memperlihatkan suatu keadaan relasional dengan Yesus sang Pokok anggur. Gambaran pokok anggur dan ranting-ranting menunjukkan suatu hubungan vital yang didasarkan pada actus percaya. Tanpa percaya, tidak ada tinggal bersama. Tanpa tinggal bersama, tidak mungkin menghasilkan buah. Oleh karena itu Yesus memberi perintah: "Tinggallah di dalam Aku!" (Yoh 15:4). Melalui iman sebagai actus percaya yang dinamis, seseorang mempertahankan kesatuan vital dengan Yesus sang Pokok anggur. ${ }^{33}$ Ungkapan "Tinggallah di dalam Aku" berarti tinggal dalam relasi istimewa dengan Dia: ${ }^{34}$ tinggal dalam relasi simbiosis antara Kristus dan umatNya. ${ }^{35}$

Gereja dalam konteks ini adalah sebuah komunitas yang diciptakan oleh Yesus, sebuah komunitas iman ${ }^{36}$ dalam Kristus yang menjadi "sebuah sakramen, yaitu tanda dan sarana dari persatuan intim dengan Allah dan dalam kesatuan dengan seluruh umat manusia". ${ }^{37}$ Bertolak dari iman dan dipadukan dalam kasih persahabatan dengan Allah, para murid menjadi anggota dalam sebuah komunitas baru dari Kerajaan Alah atau keluarga Allah. Dalam surat Yakobus

${ }^{32}$ Cfr. J. MATEOS- J. BARRETO, Il Vangelo di Giovanni, hlm. 619.

${ }^{33} \mathrm{Cfr}$. J.C. LANEY, "Abiding is Believing: the Analogy of the Vine in John 15:1-6", dalamBibliotheca Sacra 146 (1989), hlm. 65; E. BOVONE, "La fede nel Vangelo di Giovanni", hlm. 225; M. ORSATTI, Giovanni il Vangelo "Ad Alta Definizione", hlm. 174.

${ }^{34}$ Cfr. J.C. DILLOW, "Abiding is Remaining in Fellowship: Another Look at John 15:1-6", dalamBibliotheca Sacra 147 (1190), hlm. 45.

${ }^{35} \mathrm{Cfr}$. C.H. DODD, L'interpretazione del quarto vangelo, (Brescia: Paideia, 1974), hlm. 503; G. SANCHEZ MIELGO, "Imágenes eclesiales en el evangelio joánico", dalam Sciencia Tomista 131, 3 (2004), hlm. 542. ${ }^{36}$ CONCILIO ECUMENICO VATICANO II, Costituzione dogmatica Lumen Gentium sulla Chiesa (21 novembre 1964), n. 8.

${ }^{37}$ Ibid., n. 1. 
(Yak 2:23), Abraham disebut sebagai Filos Theouatau sahabat Allah, justeru karena imannya. Atas cara yang sama mereka yang memiliki iman dalam persekutuan dengan Abraham dapat disebut pula sebagai sahabat (3Yoh 15). ${ }^{38}$

Keberadaan sebagai sahabat ekuivalen dengan keberadaan sebagai rantingranting, maka keduanya menentukan keberadaan menyatu dalam Kristus sang Sahabat sejati, sang Pokok anggur sejati. Berkat pengetahuan, para murid melihat dan memahami personalitas dan kehadiran Sang Sabda yang mewahyukan Bapa dalam keberadaanNya sebagai manusia, dalam karyaNya, perkataanNya, dalam seluruh kehidupan manusiawiNya. Seraya bersatu dengan Kristus, para murid membentuk Gereja sebagai satu komunitas para sahabat: karena "mereka yang Tuhan pilih sebagai sahabat tidak dapat kehilangan perasaan bersatu di antara mereka sebagai sahabat satu sama lain. Para rasul disebut sahabat. Para sahabat mengambil bagian dalam kehidupanNya; Yesus memberitahukan kepada mereka semua rahasia BapaNya, sebagaimana biasa dilakukan di antara para sahabat". ${ }^{39}$

Sebagai sahabat Yesus, para murid menerima anugerah dari Allah yang mengasihi dan berusaha mempertahankan anugerah itu melalui pemeliharaan kebersatuan dengan Yesus karena Dia telah menyampaikan kepada mereka bahwa hanya yang bersatu dengan Dia, akan dapat menghasilkan buah. Ini berarti persekutuan dengan Yesus merupakan unsur konstitutif keberadaan sebagai sahabat dan hal itu dipertahankan melalui penghayatan perintah kasih yang diberikan Yesus.Gereja adalah komunitas para sahabat yang menerima anugerah status baru tersebut, sekaligus bertanggung jawab memelihara status itu dalam ketaatan untuk melaksanakan semua perintah kasih.Persatuan, kasih dan ketaatan seorang murid didasarkan pada model utama yaitu Yesus sendiri, yang bersatu dengan Bapa, mengasihi Bapa dan taat pada Bapa. ${ }^{40}$

\section{Kesimpulan}

Keberadaan sebagai sahabat, bukannya hamba, dalam Yoh 15:114-15, pada dasarnya merupakan sebuah status istimewa yang dihadiahkan Yesus kepada para murid. Inisiatif penganugerahan itu mendapat tanggapan positif dari para murid pilihan. Melalui pengetahuan atau iman seorang murid diarahkan pada kebenaran ilahi yang diwahyukan. Perjumpaan antara wahyu Yesus dan pengetahuan para murid merupakan momen penciptaan baru yaitu status baru keberadaan sebagai sahabat. Keberadaan baru ini dibasiskan pada perintah fundamental yang diberikan Yesus: mengasihi sebagaimana Yesus mengasihi; mengasihi Allah dan sesama sebagai perwujudan hubungan kasih dengan Yesus yang terus menerus dipertahankan dalam iman dan kasih.

\footnotetext{
${ }^{38}$ Cfr. W. GÜNTHER," $\mathrm{f} i \mathrm{le}$, w", dalamDizionario dei concetti biblici del Nuovo Testamento, hlm. 101. ${ }^{39}$ X. LÉON-DUFOUR, Dizionario di Teologia Biblica, (Genova: Casa Editrice Marietti), 2004, 43.

${ }^{40} \mathrm{Cfr}$. W. GRUNDMANN, "Das Wort von Jesu Freunden (Joh. XV, 13-16) und das Herrenmahl", dalamNovum Testamentum 3 (1959), 67.
} 
Keberadaan sebagai ranting-ranting pada Pokok anggur sejajar dengan keberadaan sebagai sahabat. Intinya adalah persatuan dengan Yesus, karena hanya mereka yang bersatu dengan Dialah yang akan mampu menghasilkan buah. Menghasilkan buah dapat disejajarkan dengan mengasihi satu sama lain. Sebagai ranting, seorang sahabat mesti tetap terikat pada Yesus sang Pokok anggur agar dapat mengasihi satu sama lain dan menghasilkan buah dalam hidup. Keberadaan sebagai sahabat adalah bentuk mendasar dari aktus berada; mengasihi satu sama lain adalah bentuk fundamental dari tindakan. Tiada perbuatan tanpa keberadaan, demikian pula tiada aktus mengasihi tanpa berada menyatu dengan Yesus.Para murid, melalui iman yakni kemampuan untuk mengetahui pewahyuan Yesus Kristus sang Pewahyu Bapa, menerima anugerah untuk berada sebagai sahabat, seraya membentuk Gereja yaitu komunitas para sahabat yang beriman. Mereka bersatu dengan Yesus sang Pokok anggur sehingga mampu mengasihi Allah dan sesama, dan dengan demikian mampu mewujudkan dan mempertahankan perintah cintakasih. Menghayati cintakasih adalah aktus prinsipil dari kaum beriman, Gereja Kristus yang adalah komunitas para sahabat. Dengan demikian, para murid sesungguhnya adalah sahabat, dan bukan hamba.

\section{Daftar Pustaka}

Barrett Charles Kingsley, The Gospel According to St. John. An Introduction with Commentary and Notes on the Greek Text, London:S. P. C. K., 1965.

Barrett Charles Kingsley, Il Vangelo di Giovanni e il Giudaismo, Brescia: Paideia, 1980.

Bovone Emilio, "La fede nel Vangelo di Giovanni", dalamParole di Vita 16, 3 (1971), 223-232.

Brown Raymond E., La Comunità del Discepolo prediletto, Assisi: Cittadella, 1982.

Brown Raymond E., Giovanni, Assisi: Cittadella Editrice, 2006.

Bultmann Rudolf - Weiser Artur, Fede nel Nuovo Testamento, Brescia: Paideia, 1995.

Casalegno Alberto, "Fede ed esperienza nella teologia di San Giovanni", dalamParole di Vita 29, 4 (1984), 301-311.

Cecolin Romano, “Gesù è la vera vigna: possibilità e condizioni di fecondità (Gv 15,116,3)", dalam Parole di Vita 49, 4 (2004), 33-40.

Concilio Ecumenico Vaticano II, Costituzione dogmatica Lumen Gentium sulla Chiesa (21 novembre 1964).

Dillow Joseph C., "Abiding is Remaining in Fellowship: Another Look at John 15:16", dalam Bibliotheca Sacra 147, 582 (1990), 44-53.

Dodd Charles Harold, L'interpretazione del quarto vangelo, Brescia: Paideia, 1998.

Fabris Rinaldo, Giovanni, Roma: Borla, 1992.

Grasso Santi, Il Vangelo di Giovanni, Brescia: Città Nuova, 2008.

Grundmann Walter, "Das Wort von Jesus Freunden (Joh XV, 13-16) und das Herrenmahl", dalamNovum Testamentum 2, 3 (1959), 62-69.

Günther Walther, "file, w", dalam Coenenlothar - Beyreuter Erich - Bietenhard Hans (ed.), Dizionario dei concetti biblici del Nuovo Testamento, Bologna:EDB, 2007, 99-102. 
Laney J. Carl, "Abiding Is Believing: The Analogy of the Vine in John 15:1-6", dalamBibliotheca Sacra 146, 581 (1989), 55-66.

Léon-Dufour Xavier, Dizionario di Teologia Biblica, Casa Editrice Marietti, Genova 2004.

Léon-Dufour Xavier, Lettura dell'evangelo secondo Giovanni, Milano: San Paolo, 2007.

Manns Frederic, "Je vous appelle mes amis", dalamBibbia e Oriente 38, 4 (1996), 227238.

Mateos Juan - Barreto Juan, Il Vangelo di Giovanni, Assisi: Cittadella Editrice, 1982.

Mateos Juan - Barreto Juan, Dizionario teologico del Vangelo di Giovanni, Assisi: Cittadella Editrice, 1982.

Mazzeo Michele, Vangelo e lettere di Giovanni, Milano: Paoline, 2007.

Michael Otto, "pi, stij", dalam Coenenlothar - Beyreuter Erich - Bietenhard Hans (ed.), Dizionario dei concetti biblici del Nuovo Testamento, Bologna: EDB, 2007, 615627.

Moloney Francis J., Il Vangelo di Giovanni, Torino: Elledici, 2007.

Nestle, Erwin - Aland, Kurt, Novum Testamentum Graece 27a, Stuttgart: Deutsche Bibelgesellschaft, 2001.

Orsatti Mauro, Giovanni il Vangelo “Ad Alta Definizione”, Milano: Ancora Editrice, 1999.

Panimolle Salvatore A., L'evangelista Giovanni, Borla, Roma 1985.

Panimolle Salvatore A., Lettura Pastorale del Vangelo di Giovanni, vol. 3, Bologna: EDB, 2002.

Pizzorni Reginaldo M., Il diritto naturale dalle origini a S. Tommaso d'Aquino, Bologna: Edizioni Studio Domenicano, 2000.

Poppi Angelico, I quattro vangeli. Commento sinottico, vol. 2, Padova: Messaggero di Sant'Antonio Editrice, 2006.

Schnackenburg Rudolf, Il Vangelo di Giovanni, vol. 3, Brescia: Paideia, 1998

Schnackenburg Rudolf, Le Parole di commiato di Gesù (Gv. 13-17), Brescia: Paideia, 1994

Segalla Giuseppe, Vangelo secondo Giovanni, Brescia: Paideia, 1998.

Simoens Yves, Secondo Giovanni. Una traduzione e un'interpretazione, EDB, Bologna 2002

Strathmann, Hermann, Il Vangelo Secondo Giovanni, Brescia: Paideia, 1973.

Wilckens Ulrich, Il Vangelo secondo Giovanni, Brescia: Paideia, 2002. 
LUMEN VERITATIS Jurnal Filsafat dan Teologi, Volume. 9, Nomor 2, Oktober 2016 - Maret 2017 pISSN: 1978-3469 